\title{
Produk Gadai Emas di Perbankan Syariah: Analisis Maslahah Ekonomi
}

\author{
Muhammad Yafiz \\ Universitas Islam Negeri Sumatera Utara \\ muhammadyafiz@yahoo.co.id \\ Darwis Harahap \\ Institut Agama Islam Negeri Padangsidimpuan \\ darwis05@yahoo.com
}

\begin{abstract}
Gold Pawn practices in Islamic Banking can give rise to speculation action due to volatility in the market price of gold. The purpose of this study was to perform stress testing whether there is a bank and the customer losses when the price of gold down by using a static simulation. The data used is secondary data that the value of (qardh) cumulative gold on Islamic banking in Indonesia started March 2004 to May 2015 year. The results of stress testing on the static simulation result of a $50 \%$ decline in gold prices shows that there are positions CAR below $8 \%$ for 3 months. Practice gold pawn is not in accordance with maslahah mursalah for having violated the rules of economic harm to banks and customers and can be considered to maslahah mulgha or maslahah sukuti where maslahah is not in accordance with personality in the economic analysis of Islam.
\end{abstract}

Keywords: static simulation, stress testing, maslahah

\begin{abstract}
Abstrak
Praktik Gadai Emas di Perbankan Syariah dapat menimbulkan tindakan spekulasi akibat volatilitas harga emas di pasar. Tujuanpenelitian ini adalah untuk melakukan stress testingapakah terdapat kerugian bank dan nasabah ketika harga emas turun dengan menggunakan simulasi statis.Adapun data yang digunakan adalah data sekunder yakni nilai gadai (qardh) emas kumulatif pada perbankan syariah di Indonesia dimulai bulan dari Maret 2004 sampai dengan Mei 2015.Hasil stress testing terhadap simulasi statis akibat penurunan harga emas $50 \%$ menunjukkan terdapat posisi CAR di bawah $8 \%$ selama 3 bulan.Praktik gadai emas ini tidak sesuai dengan maslahah mursalah karena telah melanggar kaidah ekonomi yang merugikan bagi bank dan nasabah dan dapat dikategorikan kepada maslahah mulgha atau maslahah sukuti dimana maslahah tersebut tidak sesuai dengan syara' dalam analisis ekonomi Islam.
\end{abstract}

Kata Kunci: simulasi statis, stress testing, maslahah

\section{Pendahuluan}

Investasi emas merupakan investasi yang menjanjikan pada saat ini. Selain nilainya cenderung stabil, emas juga dapat menjanjikan keuntungan dimasa yang akandatang karena nilai jualnya tetap tinggi di pasar emas. Investasi emas ini 
sering dikaitkan dengan investasi yangsesuai dengan syariah karena di dalam Alqur'an disebutkan penggunaan emas (dinar) dan perak (dirham) sebagai mata uang.

Meskipun emas dianggap investasi yang berbasis syariah namun jika tidak dilakukan dengan aturan syariah akan cenderung menjadi investasi spekulatif. Jika dilihat hadits, beberapa hadits melarang tukar menukar emas dengan emas karena takut jatuh kepada riba' fadhl.Selain itu, beberapa hadits juga melarang jual beli emas secara tidak tunai (murabahah) atau dengan cicilan.Kebolehan pengelolaan emas hanya dalam penggunaan sebagai mata uang.

Dalam hal pembiayaan di bank Syariah, ada dua jenis produk yang berkaitan dengan pembiayaan emas pada perbankan syariah, yakni gadai (rahn) emas dan cicil (murabahah) emas; yang dipraktikkan oleh beberapa bank syariah di Indonesia. Gadai (rahn) emas merupakan bentuk gadai bagi nasabah yang membutuhkan dana dengan menggadaikan emasnya. Sementara, cicilan (murabahah) emas merupakan pembelian emas secara cicilan.

Dalam praktik gadai ( $r a h n$ ) emas, nasabah yang ingin menggadaikan emas disebabkanberbagai kebutuhan pokok. Bank syariah sebagai tempat mengadaikan emas akan menaksir nilai emas nasabah kemudian memberikan dana maksimum $85 \%$ sampai dengan $90 \%$ dari taksiran harga emas oleh bank dan minimum $50 \%$ dari harga emas tersebut. Adapunjangka waktu gadai diberikan selama 4 bulan dan dapat diperpanjang lagi jika belum dapat dilunasi pokok gadai dengan membayar biaya, sebagaimana biaya awal gadai(rahn) emas dan biaya (ujroh) per bulan (Firza Ananda Riri Oktavia: 2014).

Adapun biaya-biaya yang dikeluarkan, yakni biaya awal, meliputi biayaadministrasi (materai 2 lembar) sebesar Rp.12.000,-. Kemudian biaya asuransi sebesar 0,14\% dari nilai emas yang digadaikan. Kedua biaya ini dibayar pada awal transaksi.Adapun biaya akhir yang harus dibayarkan adalah biaya penitipan sebesar 1,4\% per bulan(ujroh)daripokok pinjaman gadai. Adapun jumlah pinjaman yang dapat diambil berjumlah Rp. 500.000,- sampai dengan Rp. 250.000.000,- (Firza Ananda Riri Oktavia: 2014).

Jika dianalisa proses gadai ( $r a h n$ ) emasmaka praktik ini dapat memberikan peluang bagi spekulan untuk mencari keuntungan. Jika ditinjau dari kebutuhan gadai maka uang yang diperlukan adalah untuk kebutuhan pokok.Tetapi, toleransi pinjaman sampai 250.000.000, membuka peluang tindakan spekulasi.Ditambah 
lagi, jangka waktu yang dapat diperpanjang setelah kurun waktu empat bulan berpeluang untuk menunggu kenaikan harga emas di masa yang akan datang.

Jika seseorang membeli emas dan kemudian menggadaikan emasnya kembali dengan menunggu harga emas naik di masa yang akan datang maka kondisi ini dapat terjadi. Uang yang diperoleh dari gadai emas pertama yang digadaikan akan dapat membeli emas kedua. Demikian juga uang hasil gadai emas kedua dapat dibelikan untuk membeli emas ketiga untuk digadaikan.Emas pertama, kedua dan ketiga yang dimiliki merupakan hasil dari uang yang diperoleh dari hasil gadai emas pertama yang dijual.Dari hasil gadai ini dapat diperoleh 3 (tiga) emas dengan modal 1 (satu) emas.Praktik ini disebut dengan berkebun emas.

Upaya spekulasi ini akan dapat merugikan nasabah dan bank itu sendiri. Fluktuasi harga emas menyebabkan keuntungan dan kerugian. Jika harga emas di pasaran naik maka nasabah akan menjual emasnya dan akan memperoleh keuntungan. Namun jika harga emas turun maka nasabah akan menahan emasnya di bank syariah untuk menunggu kenaikan harga emas di pasaran. Hal ini akan merugikan bank dalam pengelolaan rasio kecukupan modal atau Capital Adequacy Ratio (CAR). Tindakan spekulasi ini akan merugikan pihak nasabah di satu sisi dan pihak bank disisi lain. Selain itu, Penumpukan modal dalam membiayai gadai emas akan mengurangi biaya investasi di sektor riel lainnya.

Jika dibandingkan dengan gadai barang-barang lain maka peluang spekulasi tidak ditemukan.Artinya, emas merupakan barang yang rentan digunakan menjadi barang yang dapat diperdagangkan secara spekulatif. Oleh karena itu, peluang emas menjadi bahan spekulatif semakin memperkuat Hadits yang melarang cicil emas akan menyebabkan terjadinya riba fadl. Sebagai gambaran, ketika harga emas turun maka nasabah akan menahan emasnya menunggu kenaikan harga emas di masa yang akan datang. Hal ini merugikan bank karena mengambil dana untuk menalangi emas tersebut. Sebaliknya, jika harga emas naik maka nasabah akan menjual emasnya. Hal ini menjadikan emas sebagai barang spekulatif.

Praktik gadai emas harus diteliti kembali agar tidak ada peluang untuk memberikan ruang spekulasi. Di satu sisi, praktisi perbankan Syariah harus mengakomodir permintaan pasar keuangan agar bank syariah mampu 
berkompetisi dengan bank lain, baik dalam produk penghimpunan dana, penyaluran dana dan pelayanan jasa yang dibutuhkan oleh masyarakat. Inovasi dan pengembangan produk bank Syariah merupakan sebuah keharusan disebabkan praktik ekonomi yang semakin kompleks sehingga diperlukan produk yang mampu bersaing dan layak jual. Namun, disisi lain syariah compliance harus diwujudkan supaya bank syariah tidak disamakan dengan bank konvensional dalam praktikya.

Inovasi baru dalam pengembangan produk bank syariah, sampai saat ini Dewan syariah Nasional Majelis Ulama Indonesia telah mengeluarkan sekitar 80 lebihfatwa yang berkaitan dengan produk bank Syariah. Legitimasi DSN MUI diakui dalam perundang-undangan untuk merumuskan prinsip-prinsip syariah dalam bidang perekonomian dan keuangan syariah. Hal ini dapat dilihat dari Surat Keputusan Direksi Bank Indonesia Nomor 32/34/1999 pasal 31 yang menyatakan: "untuk melaksanakan kegiatan-kegiatan usahanya, Bank Umum Syariah diwajibkan untuk memperhatikan fatwa DSN MUI” (M. Cholil Nafis: 2011, 83). Dalam hal ini, setiap produk yang ingin dibuat oleh bank Syariah harus meminta fatwa kepada DSN MUI untuk dasar hukum kebolehannya.

Jika dianalisa fatwa DSN No. 26/DSN-MUI/ III/2002, praktik gadai emas diakomodir dalam Fatwa Dewan Syariah Nasionaltersebut.Kebolehan gadai emas lebih kepada kebiasaan yang berlaku saat ini.Hal ini dilihat dari hadits yang dikutip para ulama bahwa gadai yang dilakukan tidak berbentuk emas tetapi barang komoditas lainnya.Namun, kebiasaan di masyarakat ini rentan terhadap tindakan spekulasi.Ketentuan yang berlaku pada hadits yang menyatakan bahwa pertukaran emas dapat terjebak kepada riba fadhl dan larangan terhadap jual beli emas secara tidak tangguh menjadi pertimbangan untuk menjadikan gadai emas sebagai objek spekulasi.Untuk itu, penulis ingin melihat bagaimana pengaruh gadai emas terhadap bank dan nasabah dari sisi kajian ekonomi Islam.

\section{Kajian pustaka}

Kata Gadai berasal dari bahasa Arab yaitu rahn, yang berarti الثبوت (tetap dan lama), yakni tetap maksudnyas الحبس واللزوم) (pengekangan dan keharusan) (Rachmat Syafe'i: 2001, 159). Ada pula yang menjelaskan bahwa rahnsecara bahasa adalah terkurung dan terjerat (Hendi Suhendi: 2008, 105). Secara terminologi syara', rahn berarti: 


$$
\text { حبس شيء بحق بمكن استفاؤه منه }
$$

Artinya: penahanan terhadap suatu barang dengan hak sehingga dapat dijadikan sebagai pembayaran dari barang tersebut (Syafe'i: 2001, 159).

Adapun menurut istilah syara':

$$
\text { عقد موضو عه احتباس مال لوفاء حق يمكن استبفاءه منه }
$$

Artinya: akad yang objeknya menahan harta terhadap sesuatu hak yang mungkin diperoleh bayaran dengan sempurna darinya (Hasbi Ash-Shiddieqy: 1984, 86-87).

Defenisi lain menyatakan:

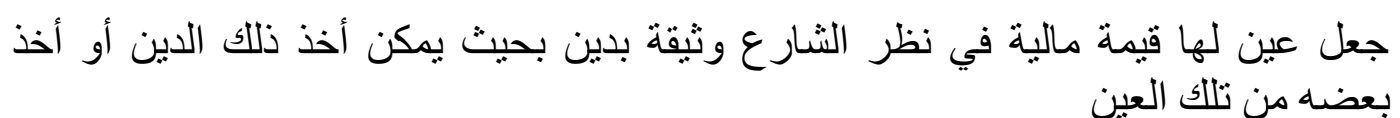

Artinya: menjadikan suatu benda berharga dalam pandangan syara' sebagai jaminan atas hutang selama ada dua kemungkinan, untuk mengembalikan uang itu atau mengambil sebagian benda itu (Hasbi Ash-Shiddieqy: 1984, 86-87).

Defenisi yang memiliki artian yang sama gadai adalah akad perjanjian pinjam meminjam dengan menyerahkan barang sebagai tanggungan hutang (Hasbi Ash-Shiddieqy: 1984, 86-87) lihat juga (Masyfuk Zuhdi: 1988, 153). Lebih ringkas mengartikan gadai, "menjadikan harta sebagai jaminan hutang" (Masyfuk Zuhdi: 1988, 153) atau menjadikan zat suatu benda sebagai jaminan hutang (Masyfuk Zuhdi: 1988, 153). Dengan kata lain, rahnadalah menahan sesuatu dengan hak yang memungkinkan untuk mengambilnya sebagai pelunasan hutang dengan menjadikan benda sebagai jaminan (Ahmad al-Syarbashi: 1981, 201). Maksudnya, gadai ialah menjadikan suatu barang yang dijadikan peneguhan atau penguat kepercayaan dalam hutang-piutang(Ahmad al-Syarbashi: 1981, 201).

Ulama Syafi'iyyah menjelaskan defenisi rahn, "menjadikan suatu benda sebagai jaminan utang yang dapat dijadikan pembayar ketika berhalangan dalam membayar utang (Syafei, 159-160). Demikian juga Ulama Hanabilah menyatakan, rahnadalah harta yang dijadikan jaminan utang sebagai pembayar harga (nilai) utang ketika yang berhutang berhalangan (tak mampu) membayar hutangnya kepada pemberi pinjaman (Syafei, 159-160).

Dapat dipahami dari defenisi-defenisi di atas bahwa gadai menjadikan harta sebagai jaminan atas hutang-piutang atau pinjam meminjam dimana harta tersebut sebagai penguat kepercayaan terhadap akad tersebut dimana terdapat pilihan mengembalikan atau mengambil barang tersebut. Jika hutang tidak dapat 
dilunasi setelah masa berakhir maka barang jaminan tersebut dapat diambil oleh si pemberi hutang tersebut.

Rahn atau gadai dalam Al-Quran ditemukan pada surat al-Baqarah: 283 sebagai berikut:

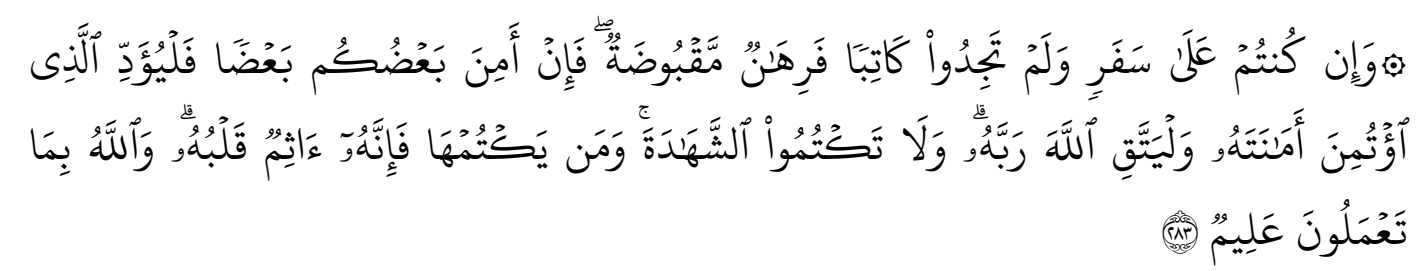

Artinya: Jika kamu dalam perjalanan (dan bermu'amalah tidak secara tunai) sedang kamu tidak memperoleh seorang penulis, maka hendaklah ada barang tanggungan yang dipegang (oleh yang berpiutang), akan tetapi jika sebagian kamu mempercayai sebagian yang lain, maka hendaklah yang dipercayai itu menunaikan amanatnya (hutangnya) dan hendaklah ia bertakwa kepada Allah Tuhannya; dan janganlah kamu (para saksi) menyembunyikan persaksian. Dan Barangsiapa yang menyembunyikannya, Maka Sesungguhnya ia adalah orang yang berdosa hatinya; dan Allah Maha mengetahui apa yang kamu kerjakan.

Menurut tafsir al-Maraghi, kata الرهان bentuk tunggal dari رهن artinya barang-barang yang dijadikan sebagai jaminan. Dalam tafsir ayat tersebut disebutkan jika dalam keadaan bepergian dan tidak menemukan juru tulis yang dapat menulis transaksi perjanjian utang piutang, atau tidak mendapatkan kertas, tinta, atau benda-benda lain yang dapat dipakai menulis, maka perkuatlah perjanjian itu dengan jaminan, yang kemudian kalian saling memeganginya (Ahmad Mustafa al-Maraghi: 1993).

Dalam ayat ini, dipahami bahwa ketiadaan penulis pada saat bepergian maka diberikan rukhsah untuk tidak memakai tulisan dan sebagai gantinya adalah jaminan dari pihak yang berhutang. Jaminan tersebut bukan menjadi milik pemberi hutang karena pemilik hutang akan mengambil barang jaminannya ketika melunasi hutangnya. Tetapi, jika si penghutang tidak mampu membayar hutangnya maka pemberi hutang boleh mengambil jaminannya (Ahmad Mustafa al-Maraghi: 1993).

Dalam ayat ini terkandung isyarat yang menjelaskan bahwa diisyaratkannya pembolehan tidak memakai penulis dalam keadaan bepergian, tidak pada waktu mukim. Oleh karena itu, hukum penulisan ini adalah wajib bagi kaum muslimin karena iman tidak dapat dibuktikan kecuali ketaatan dan 
pengamalan. Terlebih lagi jika berkaitan dengan masalah yang fardhu, seperti dalam masalah penulisan ini (Ahmad Mustafa al-Maraghi: 1993).

Sementara itu, lanjutan ayat menyatakan:

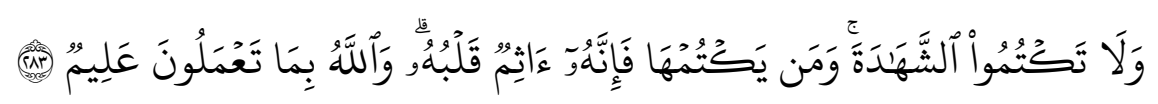

Artinya: dan janganlah kamu (para saksi) menyembunyikan persaksian.

Dan Barangsiapa yang menyembunyikannya, Maka Sesungguhnya ia adalah orang yang berdosa hatinya; dan Allah Maha mengetahui apa yang kamu kerjakan.

Ayat ini menjelaskan bahwa boleh meminta jaminan ketika tidak ada juru tulis, namun pemberi hutang juga boleh memberikan pinjaman tanpa jaminan jika si pemberi pinjaman yakin dengan si peminjam.

Dalam tafsir al-Ahkam, menafsirkan ayat pada pada surat al-Baqarah: 283 tersebutjuga dimulai dari awal ayat tersebut, yakni "Dan jika kamu di dalam perjalanan; sedang kamu tidak mendapat seorang penulis, maka hendaklah kamu pegang barang-barang agunan. Maksudnya, baik ketika berada di rumah atau dalam perjalanan, hendaklah perjanjian hutang piutang itu dituliskan. Tetapi kalau terpaksa karena penulis tidak ada, atau sama-sama terburu-buru di dalam perjalanan diantara yang berhutang dan berpiutang, maka ganti menulis, peganglah oleh yang memberi hutang itu barang agunan, atau borg, sebagai jaminan terhadap uang yang dipinjam tersebut (Hamka: 1982, 85).

Tafsiran ayat selanjutnya juga menekankan kepada pelaksanaan amanat dan menjaga barang gadaian serta tidak merusak barang gadaian tersebut atau menjualnya sebelum transaksi berakhir (Hamka: 1982, 85). Tafsir ayat tersebut menekankan adanya gadai ketika dalam perjalanan atau tidak terdapat juru tulis yang akan menuliskan suatu akad hutang piutang. Namun, Jumhur Ulama menyatakan bahwa perjalanan dan tidak adanya orang yang akan menuliskan itu, tidaklah menjadi syarat bagi sahnya gadai, karena terdapat dalam sahihain, Rasulullah saw. sendiri pernah menggadaikan baju besinya kepada orang Yahudi di Madinah. Kebalikan dari pendapat ini ialah pendapat Mujahid berkata, makruh melakukan gadai kecuali dalam perjalanan, karena berpegang pada ayat ini (Hamka: 1982, 85). hal ini dijelaskan pada Hadist berikut:

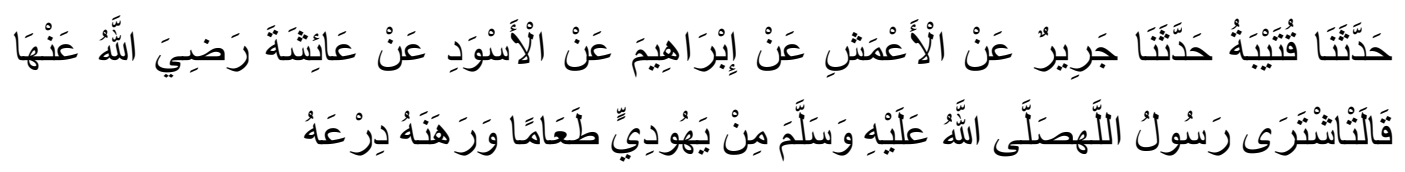


(BUKHARI - 2330): Telah menceritakan kepada kami Qutaibah telah menceritakan kepada kami Jarir dari Al A'masy dari Ibrahim dari Al Aswad dari 'Aisyah radliallahu 'anha berkata: Rasulullah shallallahu 'alaihi wasallam pernah membeli makanan dari orang Yahudi dengan menggadaikan (menjaminkan) baju besi Beliau"(Bukhory: 1992, 538).

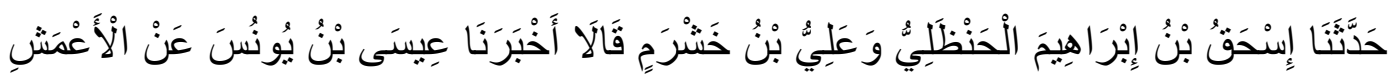

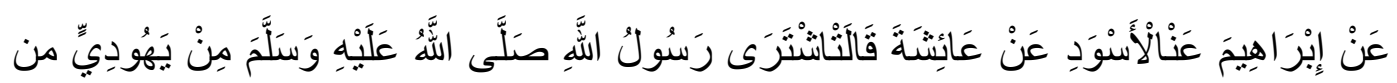

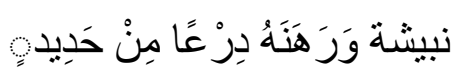

(Al-Baihaqy): Telah menceritakan kepada kami Ishaq bin Ibrahim Al Hanzhali dan Ali bin Khasyram keduanya berkata; telah mengabarkan kepada kami Isa bin Yunus dari Al A'masy dari Ibrahim dari Al Aswad dari 'Aisyah dia berkata, "Rasulullah shallallahu 'alaihi wasallam pernah membeli makanan dari seorang Yahudi, lalu beliau menggadaikan baju besinya (sebagai jaminan)." (AlBaihaqy, 517).

$$
\text { و البخاري و النس قال : رهن رسول الله صلم در عا عند يهودي بالمدينة و أخذشعر ا لأهله (رو اه أحمد }
$$

Dari Anas, katanya: "Rasulullah telah merungguhkan baju besi beliau kepada seorang Yahudi di Madinah, sewaktu beliau menghutang syair (gandum) dari orang Yahudi untuk keluarga beliau. (HR. Ahmad, Bukhari, Nasai dan Ibnu Majah)

Para ulama semuanya sependapat, bahwa perjanjian gadai hukumnya mubah (boleh). Namun ada yang berpegang pada zahir ayat, yaitu gadai hanya dibolehkan dalam keadaan bepergian saja, seperti paham yang dianut oleh Mazhab Zahiri, Mujahid dan al-Dhahak sebagaimana pemahaman ayat di atas. Sementara jumhur (kebanyakan ulama) membolehkan gadai, baik dalam keadaan bepergian maupun tidak, seperti yang pernah dilakukan oleh Rasulullah di Madinah, sebagaimana disebutkan pada Hadits-hadits di atas (M. Ali Hasan: 2004, 255).

Praktik gadai yang dilakukan Rasulullah menjadi landasan bahwa gadai diperbolehkan ketika merupakan kebutuhan masyarakat yang bersifat positif.Oleh karena itu gadai harus memenuhi syarat dan rukun. Adapun rukun gadai itu ada tiga yaitu : 
1. Aqid (orang yang melakukan akad) yang meliputi:

a) Rahin, yaitu orang yang menggadaikan barang (penggadai)

b) Murtahin, yaitu orang yang berpiutang, yang memelihara barang gadai sebagai imbalan uangyang dipinjamkan (penerima gadai).

2. Ma'qud 'alaih (yang diakadkan) yang meliputi dua hal yaitu :

a) Marhun (barang yang digadaikan)

b) Marhun bih (hutang yang karenanya diadakan gadai).

3. Sighat (akad gadai) (Abd. Ar-Rahman al-Jaziry, 320).

Dalam rukun gadai Abu Hanifah hanya mensyaratkan ijab qabul saja yang merupakan rukun akad. Beliau berpendapat bahwa ijab qabul merupak hakekat dari akad (Abd. Ar-Rahman al-Jaziry, 320).

Sedangkan menurut Zuhaili (t.t) mengatakan bahwa rukun gadai itu adalah:

1. Sighat akad ( Ijab qabul)

2. Aqid (Penggadai dan penerima gadai).

3. Marhun (barang gadaian).

4. Marhun bih (hutang) (Wahbah az-Zuhaili, 183).

Hadits yang menjelaskan gadai di atas dapat dipahami bahwa gadai bukan termasuk pada akad pemindahan hak milik, melainkan hanya sekedar jaminan untuk suatu hutang piutang, itu sebabnya ulama sepakat bahwa hak milik dan manfaat suatu benda yang dijadikan jaminan (Marhun) berada dipihak rahin (Yang menggadaikan).

Hadits yang menceritakan bahwa Rasul menyerahkan baju besinya sebagai jaminan pembelian makanan secara berhutang, dapat dipahami bahwa Rasul tidak memiliki uang. Dari riwayat ini dapat disimpulkan bahwa tujuan rahnadalah keadaan tidak memiliki uang yang sifatnya hanya sementara dan dipastikan bahwa seorang yang berhutang memiliki kemampuan untuk melunasi hutangya di kemudian hari, tanpa harus menjual barang yang dimilikinya (Saparuddin Siregar, 478).

Disamping itu, Murtahin (yang menerima barang gadai) tidak boleh mengambil manfaat barang gadai kecuali diizinkan oleh rahin dan barang gadai itu bukan binatang. Ulama Syafi'i, Imam Malik dan ulama-ulama yang lain berargumen menggunakan hadis Nabi saw. tentang manfaat barang gadai adalah milik rahin bukan milik murtahin. Hadisnya yaitu :

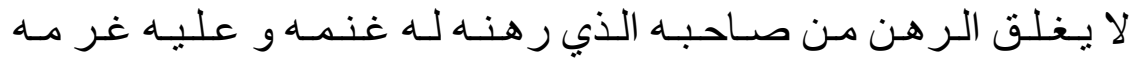

Artinya: Tidak tertutup harta yang dijaminkan dari pemiliknya, baginya keuntungan dan atas bebannya biaya pemeliharaan (Asy-Syaukani, 264). 
Dalam pemanfaatan barang gadai yang berupa barang yang bergerak dan membutuhkan pembiayaan, ulama sepakat membolehkan murtahin mengambil manfaat dari barang tersebut seimbang dengan biaya pemeliharaannya, terutama bagi hewan yang dapat diperah dan ditunggangi, mereka beralasan sesuai dengan hadis nabi saw. yang berbunyi:

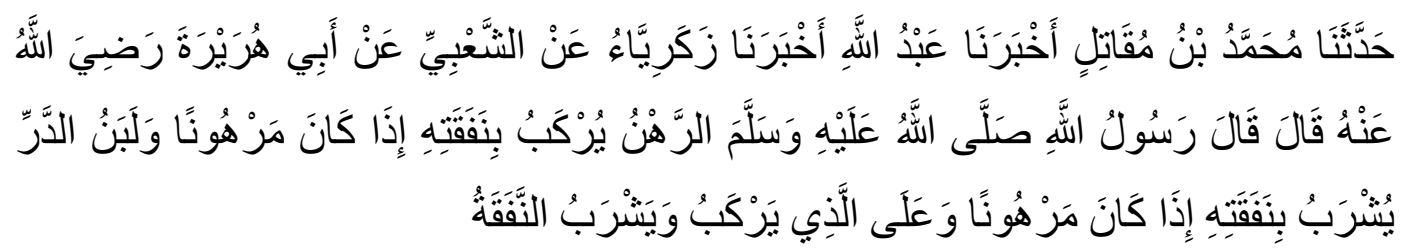

(BUKHARI - 2329) : Telah menceritakan kepada kami Muhammad bin Muqatil telah mengabarkan kepada kami 'Abdullah telah mengabarkan kepada kami Zakariya' dari Asy-Sya'biy dari Abu Hurairah radliallahu'anhu berkata; Rasulullah shallallahu 'alaihi wasallam bersabda: "(Hewan) boleh dikendarai jika digadaikan dengan pembayaran tertentu, susu hewan juga boleh diminum bila digadaikan dengan pembayaran tertentu, dan terhadap orangyang mengendarai dan meminum susunya wajib membayar" (Bukhory, 539-540).

Adapun jika barang itu tidak dapat diperah dan ditunggangi (tidak memerlukan biaya), maka dalam hal ini boleh bagi penerima gadai mengambil manfaatnya dengan seizin yang menggadaikan secara suka rela, tanpa adanya imbalan dan selama sebab gadaian itu sendiri bukan dari sebab menghutangkan. Bila alasan gadai itu dari segi menghutangkan, maka penerima gadai tidak halal mengambil manfaat atas barang yang digadaikan meskipun dengan seizin yang menggadaikan (Rahmat Syafi'I: 1995, 69).

Jika memperhatikan penjelasan di atas dapat diambil pengertian bahwa pada hakekatnya penerima gadai atas barang jaminan yang tidak membutuhkan biaya tidak dapat mengambil manfaat dari barang jaminan tersebut.Sebagaimana kaidah yang terkenal di kalangan para ulama mengatakan:

كل قرض جر منفعة فهو ربا

'Semua transaksi utang-piutang yang menyebabkan pihak pemberi piutang mendapatkan keuntungan materi adalah transaksi riba.' (Al-Son'any: 1995, 183).

Berdasarkan kaidah tersebut maka pihak yang memberi piutang tidak boleh meminta agar pihak yang berutang menyerahkan lahan pertaniannya kepada pihak yang memberi piutang, lalu pemberi piutang mengambil alih hak pengelolaan atas tanah tersebut, meski pihak yang memberi piutang memberikan sebagian hasilnya kepada pemilik tanah. Hal ini terlarang karena, dalam kasus ini, terdapat manfaat materi yang didapatkan oleh pihak yang memberi piutang. Sehingga, transaksi utang-piutang beralih fungsi dari fungsi aslinya, yaitu bersifat 
sosial untuk menolong orang yang membutuhkan (Muhammad bin Abdul Aziz Al-Musnad, 415-416)."

Penelitian Siregar (2011) menjelaskan, pada dasarnya rahnmerupakan akad tolong menolong. Namun perkembangan ekonomi menjadikan rahnmenjadi akad yang populer dan berubah menjadi business oriented. Fatwa DSN No. 26/DSN-MUI/III/2002 sebenarnya melegalkan rahnsebagaimana konsep awal yakni akad tabarru'. Meskipun bank diberikan wewenang mengambil biaya sewa atau akad tijarah dalam hal penitipan emas di bank Syariah (Saparuddin Siregar, 474).

Hal ini memang berbeda dengan konsep dasar awal rahndalam hutang piutang yang hanya memakai satu akad saja. Namun, bank Syariah sebagai lembaga bisnis yang harus mengeluarkan biaya-biaya dalam operasionalnya maka rahin diberikan biaya administrasi, sewa dan lainnya maka ditambah satu akad lagi yakni akad ijarah. Istilah modifikasi akad ini disebut sebagai al-'ukud alMurakkabah atau hybrid contract. Hal ini sah-sah saja sesuai dengan fatwa DSN MUI di atas. Tetapi ketika rahnemas ini berubah menjadifinancial enginering maka yang terjadi penyimpangan menjadi "Berkebun Emas" maka hal ini tidak sesuai lagi dengan koridor syariah.

\section{Metode penelitian}

Untuk membuktikan apakah terdapat maslahah pada praktik rahn emas maka penelitian menggunakan metode simulasi statis dengan metode stress testing. Simulasi merupakan suatu aktivitas yang menirukan operasi dan perilaku dari berbagai macam situasi nyata, baik fasilitas maupun prosesnya. Keadaan nyata yang akan disimulasikan itu dinamakan sistem, dimana untuk mempelajarinya diperlukan berbagai asumsi (Arman Hakim Nasution dan Imam Baihaqi: 2007, 1). Simulasi statis digunakan untuk melihat skenario dampak penurunan harga emas dengan asumsi 10\%, 25\% dan 50\% terhadap rasio kecukupan modal bank Syariah.

Dalam melakukan simulasi, data yang digunakan adalah data sekunder yakni nilai gadai (qardh) emas kumulatif pada perbankan syariah di Indonesia dimulai bulan dari Maret 2004 sampai dengan Mei 2015. Disamping itu, data sekunder yang digunakan adalah kurs rupiah dalam Dolar AS, harga emas per ons per Dolar AS, modal inti (tier1), modal pelengkap (tier2), laba tahun berjalan, 
Aktiva Tertimbang Menurut Risiko (ATMR) dan Rasio Kecukupan Modal (Capital Adequcy Ratio) per bulan sejak Maret 2004 sampai dengan Mei 2015.

Adapun rumus yang digunakan untuk melihat pengaruh harga emas terhadap Capital Adequacy Ratio (CAR) maka diperlukan rumus Capital Adequacy Ratio (CAR) menurut Peraturan Bank Indonesia Nomor 15/12/PBI/2013 pasal 9 tentang kewajiban penyediaan modal minimum bank umum sebagai berikut:

$C A R=\frac{\text { Modal inti }(\text { Tier } 1)+\text { Modal Pelengkap }(\text { Tier } 2)}{\text { Aktiva Tertimbang Menurut Risiko }(\text { ATMR })}$

Dalam melakukan simulasi statis maka langkah-langkah yang dilakukan adalah:

1. Menentukan data qardh emas kumulatif di Perbankan Syariah

2. Menentukan harga emas per ons dalam per Dolar AS

3. Menentukan kurs Dolar AS dalam rupiah

4. Menentukan Modal Inti (Tier1), Modal Pelengkap (Tier2) dan Aktiva Tertimbang Menurut Risiko (ATMR)

5. Menentukan equity participation

6. Menentukan laba tahun berjalan

7. Menentukan Capital Adequacy Ratio (CAR)

8. Menentukan jumlah berat emas dalam ukuran ons

9. Melakukan skenario statis jika terjadi penurunan harga emas dengan asumsi $10 \%, 25 \%$ dan $50 \%$

10. Melakukan stress testing dengan menghitung kerugian bank akibat harga emas turun dengan asumsi 10\%, 25\% dan 50\%

11. Menentukan posisi laba tahun berjalan akibat penurunan harga emas dengan asumsi turun $10 \%, 25 \%$ dan $50 \%$

12. Menentukan perubahan modal inti (tier1) yang baru dibanding modal inti (tier1) awal akibat penurunan harga emas dengan asumsi turun 10\%, 25\% dan $50 \%$

13. Menentukan perubahan modal yang baru dibanding modal awal akibat penurunan harga emas dengan asumsi turun 10\%, 25\% dan 50\%

14. Menentukan perubahan Capital Adequacy Ratio (CAR) akibat penurunan harga emas dengan asumsi turun 10\%, 25\% dan 50\% 
15. Menentukan Capital Adequacy Ratio (CAR) yang berada di bawah $8 \%$ akibat penurunan harga emas dengan asumsi turun 10\%, 25\% dan 50\%

Selanjutnya dilakukanpengujian dengan metode stress testing.

Stresstesting adalah sebuah test untuk memeriksa apakah sebuah bank akan tetap bertahan pada kondisi ekonomi/finansial yang tidak stabil (Rifki Ismal: 2011, 467). Secara khusus, stress testing memberikan informasi berapa banyak modal yang diperlukan untuk menghindarkan bank dari kondisi default karena kerugian yang sangat besar (Rifki Ismal: 2011, 467). Dalam hal ini yang ingin diuji dampak penurunan emas terhadap Capital Adequacy Ratio (CAR) atau Rasio Kecukupan Modal bank Syariah.

Adapunkegunaanstress testing adalah:

a) Untuk menyajikan penilaian risiko di masa yang akan datang

b) Untuk mengatasi keterbatasan-keterbatasan terhadap model-model dan data historis

c) Untuk mendukung komunikasi eksternal dan internal

d) Untuk menghasilkan prosedur perencanaan modal dan likuiditas

e) Untuk menginformasikan penetapan toleransi risiko sebuah bank

f) Untuk memfasilitasi perkembangan mitigasi risiko atau rencana-rencanarencana yang kemungkinan melewati lingkup kondisi yang tertekan (Rifki Ismal: 2011, 467-468).

\section{Hasil penelitian dan diskusi}

Simulasi bisnis dengan menggunakan skenario statis digunakan untuk melihat pengaruh penurunan harga emas terhadap Bank yang akan mempengaruhi CAR bank tersebut. Pengaruh penurunan harga emas tersebut dapat dijelaskan sebagai berikut:

Pertama, Skenario harga emas turun $10 \%$ menunjukkan ketika harga emas turun sebesar $10 \%$ dari harga awal setelah dipotong Loan To Value (LTV) diasumsikan sebesar 25\% maka nilai emas tersebut sebesar Rp. 6,9 miliar pada bulan Maret tahun 2004 dan pada bulan Mei 2015 sebesar Rp.794,8 miliar. Nilai terendah pada bulan Oktober 2004 sebesar Rp. 936 juta dan tertinggi sebesar 4,423 triliun pada bulan September 2011

Kedua, Skenario harga emas turun 25\% menunjukkan jika harga emas turun sebesar $25 \%$ maka maka nilai emas yang digadaikan di bank Syariah 
sebesar 5,8 miliar pada bulan Maret tahun 2004 dan pada bulan Mei 2015 sebesar Rp. 662,387 miliar. Nilai terendah sebesar Rp. 780 juta pada bulan Oktober 2004 dan tertinggi pada bulan September 2011 sebesar 3,685 triliun. Nilai ini sesuai dengan nilai awal qardh emas ketika digadaikan di bank Syariah.

Ketiga, skenario harga emas turun 50\% menunjukkan jika harga emas turun sebesar 50\% maka nilai emas yang digadaikan di bank Syariah sebesar Rp. 3,870 miliar pada bulan Maret tahun 2004 dan pada bulan Mei 2015 sebesar Rp. 441,6 miliar. Adapun nilai emas terendah sebesar Rp. 520 juta pada bulan Oktober 2004 dan tertinggi pada bulan September 2011 sebesar Rp. 2,457 triliun.

Dari hasil skenario di atas maka ditemukan kerugian bank Syariah akibat penurunan harga emas sebagai berikut:

a. Kerugian bank Syariah akibat penurunan harga emas $10 \%$

Kerugian bagi bank dan nasabah akibat penurunan emas $10 \%$ dapat dibandingkan nilai emas akibat penurunan harga emas sebesar 10\% dibandingkan dengan nilai awal qardh.Hasil simulasi menunjukkan ketika harga emas turun 10\% maka nilai emas yang digadaikan di bank sebesar Rp. 6,96 miliar. Jika dikurangi modal awal qardh gadai emas yang diberikan bank kepada nasabah sebesar Rp. 5,80 miliar maka dapat dihitung keuntungan bank sebesar Rp. 1,16 miliar pada bulan Maret tahun 2004. Dalam simulasi ini diasumsikan bahwa nasabah tidak mampu mengembalikan uang gadai emas yang diperolehnya. Maka ketika bank menjual emas tersebut maka bank mendapat keuntungan sebesar Rp. 1,16 miliar.

Demikian juga pada bulan Mei 2015, penurunan harga emas 10\% maka nilai emas di bank sebesar Rp. 794,86 miliar dikurangi modal qardh awal sebesar 662,38 miliar maka keuntungan bank sebesar Rp. 132,47 miliar. Keuntungan terendah akibat harga emas turun 10\% terjadi pada bulan Oktober 2004 sebesar Rp. 156 juta. Keuntungan tertinggi terjadi pada bulan September 2001 Rp. 737,19.

Pada tahun 2004, hasil simulasi statis dari data yang diperoleh sejak bulan Maret sampai dengan Desember selama 10 bulan menunjukkan bahwa jumlah keuntungan bank akibat penurunan harga emas 10\% sebesar Rp. 6,593 miliar.Pada tahun 2005 selama 12 bulan sejak Januari - Desember sebesar Rp. 14,368 miliar.Pada tahun 2006 selama 12 bulan sejak Januari-Desember sebesar Rp. 26,397 miliar.Pada tahun 2007 selama 12 bulan sejak Januari-Desember sebesar Rp. 101,279 miliar.Pada tahun 2008 selama 12 bulan sejak Januari-Desember 
sebesar 206,300 miliar.Pada tahun 2009 selama 12 bulan sejak Januari-Desember sebesar Rp. 390,602 miliar.Pada tahun 2010 selama 12 bulan sejak JanuariDesember sebesar Rp. 913,081 miliar.Pada tahun 2011 selama 12 bulan sejak Januari-Desember sebesar Rp. 3,573 triliun.Pada tahun 2012 selama 12 bulan sejak Januari-Desember sebesar Rp. 3,793 triliun.Pada tahun 2013 selama 12 bulan sejak Januari-Desember sebesar Rp. 3,580 triliun.Pada tahun 2014 selama 12 bulan sejak Januari-Desember sebesar Rp. 2,526 triliun.Pada tahun 2015 selama 5 bulan sejak Januari-Mei sebesar Rp. 735,012 miliar.

b. Kerugian Bank akibat penurunan harga emas $25 \%$

Dalam hal penurunan emas $25 \%$ maka dalam hal ini bank tidak mendapat kerugian dan keuntungan. Hal ini dapat dibandingkan ketika harga emas sebesar $25 \%$ maka nilai emas di bank Syariah sebesar Rp. 5.805 miliar dikurangi modal awal qardh gadai emas sebesar Rp. 5.805 miliar.Maka dapat dihitung kerugian dan keuntungan bank sebesar Rp. 0 pada bulan Maret tahun 2004. Demikian juga pada bulan Mei tahun 2015 sebesar Rp. 662 miliar dikurangi modal qardh awal sebesar Rp. 662 miliar maka nilai menjadi Rp. 0. Dalam hal ini, nasabah diasumsikan tidak mampu mengembalikan uang gadai emas yang diperolehnya.

c. Kerugian Bank akibat penurunan harga emas $50 \%$

Hasil simulasi menunjukkan bahwa pada bulan Maret 2004 bank Syariah mengalami kerugian akibat penurunan emas 50\% dimana nilai emas di bank Syariah pada bulan Maret tahun 2004 sebesar Rp. 3,870 miliar dikurangi modal awal qardh gadai emas sebesar Rp. 5,805 miliar. Maka dapat dihitung kerugian bank akibat penurunan harga emas sebesar Rp. -1,935 miliar. Demikian juga pada bulan Mei 2015, akibat penurunan harga emas 50\% maka nilai emas sebesar Rp.441,591miliar, dikurangi modal qardh awal sebesar Rp. 662,387 miliar maka kerugian bank sebesar Rp. -220,795 miliar.Kerugian terendah akibat harga emas turun $10 \%$ terjadi pada bulan September 2011 sebesar Rp. -260 juta triliun.Kerugian tertinggi terjadi pada bulan Oktober 2004 Rp. -1,228.

Adapun kerugian bank Syariah akibat harga emas turun $50 \%$ per tahun sejak tahun 2004 sampai dengan tahun 2015 dapat dilihat pada tabel berikut:

Tabel 1. Kerugian bank Syariahpertahun

\begin{tabular}{|c|c|c|}
\hline Tahun & Bulan & $\begin{array}{c}\text { Kerugian Bank Akibat } \\
\text { Harga Emas Turun 50\% per } \\
\text { Tahun }\end{array}$ \\
\hline 2004 & Maret - Desember & 10.989 .916 .667 \\
\hline
\end{tabular}




\begin{tabular}{|l|c|cr|}
\hline 2005 & Januari- Desember & - & 67.942 .686 .667 \\
\hline 2006 & Januari- Desember & - & 43.995 .300 .000 \\
\hline 2007 & Januari- Desember & - & 168.798 .653 .333 \\
\hline 2008 & Januari- Desember & - & 343.833 .780 .000 \\
\hline 2009 & Januari- Desember & - & 651.004 .533 .333 \\
\hline 2010 & Januari- Desember & - & 1.521 .802 .833 .333 \\
\hline 2011 & Januari- Desember & - & 5.955 .492 .341 .936 \\
\hline 2012 & Januari- Desember & - & 6.321 .956 .723 .580 \\
\hline 2013 & Januari- Desember & - & 5.967 .084 .712 .740 \\
\hline 2014 & Januari- Desember & - & 4.210 .696 .484 .643 \\
\hline 2015 & Januari- Mei & - & 1.225 .020 .578 .128 \\
\hline
\end{tabular}

Pada tahun 2004, data yang diperoleh sejak bulan Maret sampai dengan Desember selama 10 bulan.Jumlah kerugian akibat penurunan harga emas 50\% sebesar Rp. -10,989miliar.Pada tahun 2005 selama 12 bulan sejak JanuariDesember sebesar Rp. -67,942 miliar.Pada tahun 2006 selama 12 bulan sejak Januari-Desember sebesar Rp. -43,995 miliar.Pada tahun 2007 selama 12 bulan sejak Januari-Desember sebesar Rp. -168,798 miliar.Pada tahun 2008 selama 12 bulan sejak Januari - Desember sebesar Rp. -343,833 miliar.Pada tahun 2009 selama 12 bulan sejak Januari - Desember sebesar Rp. -651,004 miliar.Pada tahun 2010 selama 12 bulan sejak Januari-Desember sebesar Rp. -1,521 triliun.Pada tahun 2011 selama 12 bulan sejak Januari-Desember sebesar Rp. -5,955 triliun.Pada tahun 2012 selama 12 bulan sejak Januari-Desember sebesar Rp. 6,321 triliun.Pada tahun 2013 selama 12 bulan sejak Januari-Desember sebesar Rp. -5,967 triliun.Pada tahun 2014 selama 12 bulan sejak Januari-Desember sebesar Rp. -4,210 triliun.Pada tahun 2015 selama 5 bulan sejak Januari-Mei sebesar Rp. -1,225 miliar.

Demikian juga hasil simulasi statis pada Laba Tahun Berjalan akanmenanggung kerugian akibat harga emas turun. Hal ini dapat dijelaskan sebagai berikut:

a. Posisi Laba Tahun Berjalan menanggung kerugian akibat harga emas turun sebesar $10 \%$.

Posisi laba tahun berjalan masih positif karena bank mengalami keuntungan ketika harga emas turun sebesar 10 persen. Pada bulan Maret tahun 2015 jumlah laba tahun berjalan sebesar Rp. 8,624 miliar ditambah dengan keuntungan bank akibat harga emas turun 10\% sebesar Rp. 1,161 miliar maka keuntungan sebesar Rp. 9,785 miliar pada bulan Maret tahun 2004. Sementara itu, pada bulan Mei tahun 2015 posisi laba tahun berjalan Rp. 1,317 miliar ditambah 
dengan keuntungan bank akibat harga emas turun 10\% sebesar Rp. Rp. 132,477 miliar kerugian modal sebesar Rp. 133,794 miliar.keuntungan terendah terjadi pada bulan Januari 2006 sebesar Rp. 3,007 miliar dan tertinggi pada bulan September 2011 sebesar Rp. 1,146 triliun.

Jika dianalisa secara ekonomi maka praktik gadai emas tersebut menguntungkan bank karena memperoleh keuntungan yang tinggi. Namun, di satu pihak akan merugikan nasabah jika diasumsikan nasabah tidak mampu mengembalikan uang gadai yang menjadi piutang bagi bank. Padahal tujuan dari gadai tersebut merupakan untuk membantu sesorang mengalami kesulitan keuangan namun jika nasabah mampu mengembalikan hutang gadai maka nasabah masih mendapatkan keuntungan dari penjualan nilai awal harga emas yang digadaikan.

Pada bulan Maret tahun 2015 misalnya, ketika nasabah tidak mampu mengembalikan hutang gadai kepada bank maka nasabah tersebut mengalami kerugian akibat harga emas turun 10\% sebesar Rp. 1,161 miliar pada bulan Maret tahun 2004.Namun jika nasabah mampu mengembalikan hutang gadai maka nasabah masih mendapatkan sisa uang dari penjualan harga emas pada harga pasar bulan tersebut.

Dalam hal ini, dapat dikatakan bank memperoleh riba dari kelebihan pembayaran dari harga pokok awal akibat penurunan harga emas ketika nasabah yang menggadaikan emas tidak mampu membayar emasnya.Sementara jika emas tersebut dijual di pasar emas maka harganya melebihi nilai qardh awal yang diberikan kepada nasabah. Menurut Hadits ini bertentangan dengan niat awal gadai sebagai akad tabarru'

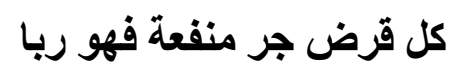

'Semua transaksi utang-piutang yang menyebabkan pihak pemberi piutang mendapatkan keuntungan materi adalah transaksi riba.'(Al-Son'any: 1995, 183).

Kelebihan yang diperoleh bank akibat ketidakmampuan nasabah membayar hutang maka termasuk kepada riba nasi,ah. Meskipun secara tidak langsung nasabah tidak diminta untuk mengembalikan uang melebihi pinjamannya namun ketika emas yang digadaikan tersebut dijual di pasar emas maka harga emas melebihi pinjaman.Ketidakmampuan nasabah membayar hutang gadai juga disebabkan akibat ketidakpastian harga emas di pasar emas. Ketidakpastian tersebut menimbulkan keuntungan di satu pihak dan merugikan di 
pihak lain. Dalam hal ini, jika nasabah tidak mengetahui fluktuasi harga emas yang menyebabkan kerugian bagi nasabah sementara bank syariah mengetahui fluktuasi harga emas di pasaran maka praktik ini termasuk gharar.

Secara teori,ada beberapa unsur yang menyebabkan larangan yang terdapat pada gharar: 1) ketiadaan ('adam) barang usaha atau 2) ketidaktahuan (jahala) tentang aspek-aspek material transaksi (Frank E. Vogel dan Samuel L. Hayes: 2007, 114). Pelarangan gharar memberikan implikasi bahwa partner bisnis seharusnya mengetahui secara tepat kerugian yang ditawarkan pada saat transaksi. Kata gharar dalam bahasa arab dikonotasikan kepada tipu muslihat atau penipuan. Tentu, risiko tidak akanpernah dapat dihindarkan secara total oleh pengusaha, dan tidak ada kegiatan produktif dan bersifat komersial yang luput dari risiko dan ketidakpastian (Hans Visser: 2009, 45), pelarangan gharar didasarkan pada tranparansi dan keadilan. Untuk menghidari gharar kedua belah pihak dalam melakukan kontrak harus:

1. Yakin bahwa barang dan harga penjualan ada, dan kedua belah pihak dapat menerima

2. Berikan karakteristik khusus dan jumlah kemungkinan kerugian

3. Berikan kuantitas, kualitas dan waktu penerimaan di masa yang akan datang (Hans Visser: 2009, 45).

Dari sisi mashlahah maka praktik gadai emas ini menimbulkan kerugian bagi nasabah.Gadai dalam bentuk emas dalam sejarah Islam tidak pernah dilakukan nabi dan para sahabat serta tidak ditemukan dalam literatur fiqh.Jika dilihat dari aspek hukum Islam maka praktik gadai emas termasuk kepada mashlahah mursalah, yakni maslahah yang tidak diatur dalam Alquran dan AlHadits namun tidak bertentangan dengan maslahah.Namun, dari praktik gadai emas ditemukan unsur yang dapat memberikan kerugian bagi nasabah, maka praktik gadai ini dapat dikategorikan kepada maslahah mulghaa.Maslahah Mulghaa atau maslahat yang dibatalkan syariah yaitu: Semua maslahat yang menyalahi hukum Syariah disebabkan praktik gadai emas tersebut merugikan nasabah.

b. Posisi Laba Tahun Berjalan menanggung kerugian akibat harga emas turun $25 \%$.

Laba tahun berjalan akan berkurang jika terjadi kerugian bank Syariah. Namun, kerugian bank yang diasumsikan sebesar 25\% sama dengan nilai Loan To 
Value (LTV) terhadap emas nasabah maka bank tidak mengalami kerugian. Ketika harga emas turun $25 \%$, maka laba tahun berjalan tidak mengalami kerugian karena laba tahun berjalan sebesar Rp. 8,624 miliar tidak digunakan untuk menutupi kerugian bank akibat harga emas turun 25\%.Hal ini dapat dilihat pada bulan Maret tahun 2004. Penurunan harga emas sebesar 25\% menyebabkan harga emas dalam nilai LTV sama dengan ketika harga emas turun sebesar $25 \%$ sehingga kerugian laba tahun berjalan bank sebesar Rp. 0. Sementara itu, pada bulan Mei 2015 laba tahun berjalan mencapai Rp. 1,317 miliar tidak digunakan untuk mencover kerugian. Laba tahun berjalan terendah terjadi pada bulan Januari 2012 sebesar Rp. 127 juta dan tertinggi pada bulan September 2011 sebesar Rp. 409,120 miliar.

Jika dianalisa secara ekonomi maka praktik gadai emas tersebut tidak menguntungkan bank karena harga emas di pasar sama dengan harga emas dalam bentuk qardh sehingga ketika bank menjual emas nasabah yang tidak mampu mengembalikan hutang gadai maka keuntungan bank tidak ada. Namun, di satu pihak akan merugikan nasabah jika diasumsikan nasabah tidak mampu mengembalikan uang gadai yang menjadi piutang bagi bank. Hal ini disebabkan nilai awal emas nasabah menurun disebabkan penurunan harga emas pada bulan tersebut.Namun meskipun nasabah mampu mengembalikan hutang gadai maka nasabah nasabah tidak mendapatkan sisa uang dari penjualan harga emas pada harga pasar bulan tersebut.Dari sisi mashlahah maka praktik gadai emas ini menimbulkan kerugian bagi nasabah.

c. Posisi Laba Tahun Berjalan menanggung kerugian akibat harga emas turun $50 \%$.

Kerugian akibat harga emas menurun $50 \%$ terhadap laba tahun berjalan dapat diketahui pada bulan Maret 2004 laba tahun berjalan sebesar Rp. 8,6 milyar. Kemudian penurunan harga emas 50\% sebesar Rp. -1,9 miliyar menyebabkan laba tahun berjalan bank Syariah mengalami penurunan menjadi Rp. 6,6 milyar.

Penurunan laba tahun berjalan yang signifikan terjadi pada bulan Januari 2006 sebesar Rp.-1,2 milyar. Kerugian ini disebabkan oleh penurunan harga emas sebesar 50\% dengan jumlah kerugian sebesar Rp. 1,4 milyar. Kerugian terjadi kembali pada bulan Januari 2008 sebesar Rp. -6,5 milyar. Kerugian selanjutnya akibat penurunan harga emas 50\% terjadi pada bulan Januari 2009 sebesar Rp. - 
24,3 milyar dan bulan Pebruari 2009 sebesar Rp. -8,4 milyar. Kerugian terakhir terjadi pada bulan Mei 2015 sebesar Rp. -219,4 milyar. Sementara, dari simulasi statis diketahui kerugian terendah terjadi pada bulan Januari 2006 sebesar Rp. -1,2 milyar dan tertinggi pada bulan September 2011 sebesar Rp. -819,5 milyar.

Adapun kerugian bank Syariah akibat harga emas turun 50\% per tahun sejak tahun 2004 sampai dengan tahun 2015 dapat dilihat pada tabel berikut:

Tabel 2. Kerugian bank Syariah akibat harga emas turun $50 \%$ per tahun

\begin{tabular}{|c|c|c|c|c|}
\hline Tahun & Bulan & $\begin{array}{c}\text { Laba Tahun } \\
\text { Berjalan }\end{array}$ & $\begin{array}{c}\text { Posisi Laba Tahun } \\
\text { berjalan }\end{array}$ & $\begin{array}{c}\text { Posisi Laba Tahun } \\
\text { berjalan menanggung } \\
\text { kerugian akibat harga } \\
\text { emas turun 50\% per } \\
\text { Tahun }\end{array}$ \\
\hline 2004 & Mar-Des & 471.741 .000 .000 & 460.751 .083 .333 & 10.989 .916 .667 \\
\hline 2005 & Jan- Des & 753.753 .000 .000 & 729.805 .613 .333 & 23.947 .386 .667 \\
\hline 2006 & Jan- Des & 357.777 .000 .000 & 313.781 .700 .000 & 43.995 .300 .000 \\
\hline 2007 & Jan- Des & 865.302 .000 .000 & 696.503 .346 .667 & 168.798 .653 .333 \\
\hline 2008 & Jan-Des & 1.253 .008 .000 .000 & 909.174 .220 .000 & 343.833 .780 .000 \\
\hline 2009 & Jan-Des & 1.756 .756 .000 .000 & 1.105 .751 .466 .667 & 651.004 .533 .333 \\
\hline 2010 & Jan-Des & 2.628 .951 .000 .000 & 1.107 .148 .166 .667 & 1.521 .802 .833 .333 \\
\hline 2011 & Jan-Des & 2.353 .245 .750 .000 & -3.602 .246 .591 .936 & -1.249 .000 .841 .936 \\
\hline 2012 & Jan-Des & 16.748 .000 .000 & -6.305 .208 .723 .580 & -6.288 .460 .723 .580 \\
\hline 2013 & Jan-Des & 24.331 .935 .000 & -5.942 .752 .777 .740 & -5.918 .420 .842 .740 \\
\hline 2014 & Jan-Des & 15.308 .493 .345 & -4.195 .387 .991 .297 & -4.180 .079 .497 .952 \\
\hline 2015 & Jan- Mei & 3.624 .685 .877 & -1.221 .395 .892 .251 & -1.217 .771 .206 .373 \\
\hline
\end{tabular}

Tabel di atas menjelaskan bahwa pada bulan Maret sampai dengan Desember 2004 jumlah laba tahun berjalan pertahun sebesar Rp. 471 milyar.Sementara akibat penurunan harga emas 50\% maka laba tahun berjalan berkurang menjadi Rp. 460 milyar.Laba tahun berjalan berkurang sebesar Rp. 10 milyar.Pada tahun 2005 sejak Januari sampai dengan Desember 2005, laba tahun berjalan sebesar Rp. 753 milyar.Sementara akibat penurunan emas sebesar 50\% maka laba tahun berjalan berkurang menjadi Rp. 729 milyar maka kerugian bank akibat laba tahun berjalan berkurang sebesar Rp. 23 milyar.

Demikian juga pada tahun 2006 laba tahun berjalan menanggung kerugian sebesar Rp. 43 milyar. Pada tahun 2007 sebesar Rp. 168 milyar, tahun 2008 sebesar Rp. 343 milyar, tahun 2009 kerugian bank mencapai sebesar Rp. 651 milyar dan pada tahun 2010 laba tahun berjalan berkurang sebesar Rp. 1,521 triliun. Adapun tahun 2011 laba tahun berjalan menjadi negatif akibat penurunan harga emas sebesar Rp.-1,249 trilyun, tahun 2012 Rp. -6,288 trilyun, tahun 2013 sebesar Rp. 5,918 trilyun, tahun 2014 kerugian sebesar Rp. 4,180 triliun dan pada 
tahun 2015 selama 5 bulan sejak Januari sampai dengan Mei 2015 mencapai Rp.

\section{1,217 triliun.}

Jika dianalisa secara ekonomi maka praktik gadai emas tersebut akan merugikan kedua belah pihak, baik bank maupun nasabah. Ketidakmampuan nasabah membayar hutang gadai juga disebabkan akibat ketidakpastian harga emas di pasar emas. Demikian juga dari sisi bank akan mengalami kerugian akibat ketikakpastian harga pasar emas. Ketidakpastian tersebut menimbulkan kerugian kedua belah pihak.Dalam hal ini, nasabah tidak mengetahui fluktuasi harga emas yang menyebabkan kerugian bagi nasabah sementara bank syariah juga tidak mengetahui fluktuasi harga emas di pasaran maka praktik ini termasuk gharar.

Dari sisi mashlahah maka praktik gadai emas ini menimbulkan kerugian bagi nasabah dan bank.Maka praktik gadai emas ini pada awalnya termasuk kepada mashlahah mursalah, yakni maslahah yang tidak diatur dalam Alquran dan Al-Hadits namun tidak bertentangan dengan maslahah.Namun, dari praktik gadai emas ditemukan unsur yang dapat memberikan kerugian bagi nasabah dan bank, maka praktik gadai ini dapat dikategorikan kepada maslahah mulghaa.Maslahah Mulghaa atau maslahat yang dibatalkan syariah yaitu: Semua maslahat yang menyalahi hukum Syariah disebabkan praktik gadai emas tersebut merugikan nasabah dan bank.

Demikian juga halnya tier 1 akanberkurang akibat penurunan harga emas $10 \%, 25 \%$ dan 50\%Pengurangan laba tahun berjalan akibat penurunan harga emas akan akan mengurangi modal inti (tierl). Penurunan harga emas mempengaruhi Tierl dalam menanggung modal akibat penurunan harga emas sehingga terjadi perubahan modal inti (tierl) yang baru untuk menanggung kerugian tersebut.

a. Tier 1 Berkurang akibat penurunan harga emas sebesar $10 \%$

Jika harga emas sebesar turun 10\% maka modal inti bank (tierl) berkurang menjadi Rp. 365 miliar dimana modal inti (tierl) sebelum penurunan harga emas 10\% sebesar Rp. 370 milyar. Pengurangan modal inti sebesar Rp. 4,8 milyar tersebut diambil dari modal inti (tierl) ditambah 50\% dari laba tahun berjalan. Hal ini dapat dilihat pada bulan Maret 2004.Sementara pada bulan Mei 2015 modal inti (tierl) bank berkurang menjadi Rp. 16,974 triliun.Pengurangan modal inti (tier1) menjadi Rp. 66 milyar.Sementara modal inti awal sebesar Rp. 17,041 
trilyun. Modal inti (tierl) terendah terjadi pada bulan Juli 2004 sebesar Rp. 292,225 miliar dan tertinggi pada bulan Mei 2014 sebesar Rp. 30,615 triliun.

b. Tier 1 Berkurang akibat penurunan harga emas sebesar $25 \%$

Ketika harga emas turun sebesar $25 \%$ maka modal inti (tierl) yang harus disediakan oleh bank akan berkurang menjadi Rp. 366,138 miliar yang diambil dari modal inti (tier1) ditambah 50\% dari laba tahun berjalan. Hal ini dapat dibandingkan dengan modal inti awal sebesar 370 milyar pada bulan Mei 2004. Jumlah pengurangan modal inti (tierl) sebesar Rp. 4,3 milyar. Sementara pada bulan Mei 2015 modal inti yang baru menjadi Rp. 17.041.123.813.197 triliun dimana modal inti (tier1) awal sebesar Rp. 17.041.783.000.000. Maka jumlah modal inti (tierl) berkurang sebesar Rp. 658.714.403,-. Nilai modal inti (tier1) terendah pada bulan Juli 2004 sebesar Rp. 292,682 miliar dan modal inti (tierl) tertinggi pada bulan Mei 2014 sebesar Rp. 30,722 triliun.

c. Tier 1 Berkurang akibat penurunan harga emas sebesar $50 \%$

Jika harga emas turun 50\% maka modal inti tierl) berkurang menjadi Rp. 367,105 miliar yang diambil dari modal inti (tier1) ditambah 50\% dari laba tahun berjalan sementara jumlah modal inti (tier1) awal sebesar Rp. 370,450 milyar. Hal ini dapat dilihat pada bulan Mei 2004. Pengurangan modal inti (tierl) berjumlah 3,3 milyar. Jika dilihat jumlah modal inti (tierl) pada bulan Mei 2015 maka modal inti (tierl) menjadi Rp. 16,822 triliun sementara modal inti (tierl) awal sebesar Rp. 17.041.783. Pengurangan modal inti (tier1) sebesar Rp. 219,4 milyar. Nilai modal inti (tier1) terendah sebesar Rp. 293,443 miliar pada bulan Juli 2004 dan modal inti (tier1) tertinggi sebesar Rp. 30,369 triliun pada bulan Mei 2014.

Penurunan harga emas akan menyebabkan penambahan modal untuk menanggulangi kekurangan dana sebagaimana dijelaskan sebagai berikut:

a. Pengurangan Modal akibat penurunan harga emas sebesar $10 \%$.

Akibat penurunan harga emas $10 \%$ bulan Maret tahun 2004 maka modal baru berkurang menjadi Rp. 427 milyar dibanding modal awal sebesar Rp. 432 milyar. Modal awal ini terdiri dari modal inti (tier1) sebesar Rp. 370 milyar ditambah modal pelengkap (tier2) sebesar Rp. 62 milyar. Selisih modal awal dengan modal baru akibat penurunan harga emas $10 \%$ menjadi Rp. 4,8 milyar.

Sementara, pada bulan Mei 2015, penurunan harga emas sebesar $10 \%$ menyebabkan penurunan modal yang baru menjadi Rp. 20,932 trilyun dibanding modal awal sebesar Rp. 20,999 triliun. Modal awal tersebut terdiri modal inti 
(tier1) awal sebesar Rp. 17,04 trilyun ditambah modal pelengkap (tier2) Rp. 3,95 triliun. Selisih modal awal dan modal baru sebesar Rp. 66 milyar. Adapun penurunan modal baru terendah terjadi pada bulan Juli 2004 sebesar Rp. 369,72 milyar dan tertinggi pada bulan Mei 2014 sebesar Rp. 34,09 triliun.

Penurunan modal akan berdampak pada penurunan persentase Rasio Kecukupan Modal atau Capital Adequacy Ratio (CAR). Sebab, rumus dari dari CAR adalah modal dibagi Aktiva Tertimbang menurut Risiko (ATMR). Penurunan modal akan mengurangi nilai CAR bank. Penurunan modal akan menyebabkan pengurangan pada pembiayaan sektor riel lainnya.

b. Pengurangan Modal akibat penurunan harga emas akibat penurunan harga emas sebesar $25 \%$.

Akibat penurunan harga emas 25\% bulan Maret tahun 2004 maka modal baru berkurang menjadi Rp. 428 milyar dibanding dengan modal awal sebesar Rp. 432 milyar. Modal awal ini terdiri dari modal inti (tierl) sebesar Rp. 370 milyar ditambah modal pelengkap (tier2) sebesar Rp. 62 milyar. Selisih modal awal dengan modal baru akibat penurunan harga emas $25 \%$ menjadi Rp. 4,3 milyar.

Sementara, pada bulan Mei 2015, penurunan harga emas sebesar 25\% menyebabkan penurunan modal yang baru menjadi Rp. 20,998 triliun dibanding modal awal sebesar Rp. 20,999 triliun. Modal awal tersebut terdiri modal inti (tier1) awal sebesar Rp. 17,04 triliun ditambah modal pelengkap (tier2) Rp. 3,95 triliun. Selisih modal awal dan modal baru sebesar Rp. 658.714.403.Adapun penurunan modal baru terendah terjadi pada bulan Juli 2004 sebesar Rp. 370 milyar dan tertinggi pada bulan Mei 2014 sebesar Rp. 34,19 triliun.Penurunan modal bank akan berdampak pada penurunan persentase Rasio Kecukupan Modal atau Capital Adequacy Ratio (CAR). Oleh karena itu, penurunan modal akan menyebabkan pengurangan pada pembiayaan sektor riel lainnya.

c. Pengurangan Modal akibat penurunan harga emas akibat penurunan harga emas sebesar $50 \%$.

Akibat penurunan harga emas 50\% bulan Maret tahun 2004 maka modal baru berkurang menjadi Rp. 429,150 milyar dibanding dengan modal awal sebesar Rp. 432 milyar. Modal awal ini terdiri dari modal inti (tierl) sebesar Rp. 370 milyar ditambah modal pelengkap (tier2) sebesar Rp. 62 milyar. Selisih modal 
awal dengan modal baru akibat penurunan harga emas 50\% menjadi Rp. 3,34 milyar.

Sementara, pada bulan Mei 2015, penurunan harga emas sebesar 50\% menyebabkan penurunan modal yang baru menjadi Rp. 20,77 trilyun dibanding modal awal sebesar Rp. 20,999 triliun. Modal awal tersebut terdiri modal inti (tier1) awal sebesar Rp. 17,04 triliun ditambah modal pelengkap (tier2) Rp. 3,95 triliun. Selisih modal awal dan modal baru sebesar Rp. 219,4 milyar. Adapun penurunan modal baru terendah terjadi pada bulan Juli 2004 sebesar Rp. 370,9 milyar dan tertinggi pada bulan Mei 2014 sebesar Rp. 33,84 triliun.

Penurunan modal bank di atas sebaimana dijelaskan akan berdampak pada penurunan persentase Rasio Kecukupan Modal atau Capital Adequacy Ratio $(C A R)$. Oleh karena itu, penurunan modal akan menyebabkan pengurangan pada pembiayaan sektor riel lainnya.

\section{Analisa Stress Testing}

Analisa stress Testing dapat dilihat dari perbandingan antara CAR aktual dan CAR akibat penurunan harga emas dalam kurun waktu 136 bulan sejak Maret 2004 sampai dengan Mei 2015. Dari hasil simulasi diperoleh posisi Capital Adequacy Ratio (CAR) akibat penurunan harga emas sebagai berikut:

a. Posisi Capital Adequacy Ratio akibat penurunan harga emas $10 \%$

Dalam kurun waktu 135 bulan sejak bulan Maret 2004 sampai dengan Mei 2015 terjadi posisi CAR akibat penurunan harga emas sebesar 10\% dapat digambarkan pada ditemukan pada bulan Maret 2004 sebesar 14,06 persen dan pada bulan Mei 2015 sebesar 14,15 persen. CAR terendah dapat dilihat pada bulan Oktober 2007 sebesar 7,68 persen dan tertinggi terjadi pada bulan Mei 2014 sebesar 30,95 persen.

Adapun posisi CAR di bawah $8 \%$ sesuai dengan ketentuan BI maka CAR yang melewati batas minimum terjadi pada bulan Oktober 2007 sebesar 7,68 persen, pada bulan November 2010 sebesar 7,75, bulan November 2007 sebesar 7,86 persen, bulan April 2008 sebesar 7,93 persen, bulan Agustus 2008 sebesar 7,95 persen dan pada bulan Mei 2008 sebesar 7,96 persen.

Dampak penurunan CAR berdampak kepada penyaluaran pembiayaan pada sektor riel lainnya. Disamping itu, penurunan CAR di bawah 8\% akan melanggar ketentuan Bank Indonesia.Jika CAR bank di bawah 8 persen, maka 
bank tersebut dalam keadaan tidak sehat. Selain itu, CAR di bawah 8 persen maka bank tersebut akan sulit melakukan transaksi skala internasional.

b. Posisi Capital Adequacy Ratio akibat penurunan harga emas $25 \%$

Dalam kurun waktu 135 bulan sejak bulan Maret 2004 sampai dengan Mei 2015 terjadi posisi CAR akibat penurunan harga emas sebesar 25\% dapat ditemukan bulan Maret 2004 Capital Adequacy Ratio (CAR) akibat penurunan harga emas $25 \%$ menurun menjadi 14,08 persen dibandingkan dengan CAR aktual sebesar 14,37\%. Adapun pada bulan Mei 2015 CAR akibat penurunan harga emas $25 \%$ menaik menjadi 14,20\% dibandingkan dengan CAR aktual sebesar 14,15. CAR terendah dapat dilihat pada bulan Oktober 2007 sebesar 7,78\% dan tertinggi terjadi pada bulan Mei 2014 sebesar 31,05\%.

Adapun posisi CAR di bawah $8 \%$ sesuai dengan ketentuan BI maka CAR yang melewati batas minimum terjadi pada bulan Oktober 2007 sebesar 7,78 persen, pada bulan November 2007 sebesar7,91 persen, bulan November 2010 sebesar 7,95 persen dan bulan April 2008 sebesar7,99 persen.

Dampak penurunan CAR di bawah $8 \%$ sebagaimana terjadi pada beberapa bulan di atas berdampak kepada penyaluaran pembiayaan pada sektor riel lainnya. Disamping itu, penurunan CAR di bawah $8 \%$ akan melanggar ketentuan Bank Indonesia.Jika CAR bank di bawah 8 persen, maka bank tersebut dalam keadaan tidak sehat. Selain itu, CAR di bawah 8 persen maka bank tersebut akan sulit melakukan transaksi skala internasional.

c. Posisi Capital Adequacy Ratio akibat penurunan harga emas 50\%

Dalam kurun waktu 135 bulan sejak bulan Maret 2004 sampai dengan Mei 2015 terjadi posisi CAR akibat penurunan harga emas sebesar 50\% dapat ditemukan pada bulan Maret 2004 Capital Adequacy Ratio (CAR) akibat penurunan harga emas $25 \%$ menurun menjadi $14,11 \%$ dibandingkan dengan CAR aktual sebesar 14,37\%. Adapun pada bulan Mei 2015 jumlah CAR akibat penurunan harga emas sebesar $25 \%$ meningkat menjadi $14,05 \%$ dibanding jumlah CAR aktual sebesar Rp. 14,20. Sementara, jumlah CAR terendah dapat dilihat pada bulan September 2011 sebesar 7,71 \% dan tertinggi terjadi pada bulan Mei 2014 sebesar $30,73 \%$.

Adapun posisi CAR di bawah $8 \%$ sesuai dengan ketentuan BI maka CAR yang melewati batas minimum terjadi pada bulan September 2011 sebesar 7,71\%, 
pada bulan Oktober 2007 sebesar 7,93\% dan pada bulan November 2007 sebesar $7,99 \%$

Hasil simulasi menunjukkan bahwa penurunan CAR di bawah $8 \%$ berdampak kepada penyaluaran pembiayaan pada sektor riel lainnya. Disamping itu, penurunan CAR di bawah 8\% akan melanggar ketentuan Bank Indonesia.Jika CAR bank di bawah 8 persen, maka bank tersebut dalam keadaan tidak sehat. Selain itu, CAR di bawah 8 persen maka bank tersebut akan sulit melakukan transaksi skala internasional.

\section{Kesimpulan}

Hasil stress testing dengan simulasi statisditemukan kerugian bagi bank dan nasabah. Jika dilihat praktik gadai emas dalam simulasi statis, terjadi kerugian bank sehingga menyebabkan laba tahun berjalan berkurang dan modal yang terdiri dari modal inti (tier1) dan modal pelengkap (tier2) berkurang akibat penurunan harga emas. Demikian juga analisa stress testing ditemukan akibat penurunan harga emas menyebabkan modal sehingga terjadi penurunan rasio kecukupan modalatau Capital Adequacy Ratio (CAR) akibat penurunan harga emas di bawah 8 persen. Penurunan modal akan mengurangi investasi pada sektor riel lainnya. Disamping itu, penurunan CAR di bawah $8 \%$ akan melanggar ketentuan Bank Indonesia.

Praktik ini tidak sesuai dengan maslahah mursalah karena telah melanggar kaidah ekonomi yang merugikan bagi bank dan nasabah.Jika demikan maka praktik gadai emas ini dapat dikategorikan kepada maslahah mulgha atau maslahah sukuti dimana maslahah tersebut tidak sesuai dengan syara' dalam analisa ekonomi Islam.Kemaslahatan yang hendak dicapai oleh syari'ah bersifat umum dan universal.Bersifat umum artinya bahwa hal itu berlaku bukan hanya untuk individu secara pribadi, melainkan juga semua manusia secara kolektif dan keseluruhan.Bersifat universal artinya bahwa kemaslahatan itu berlaku bukan untuk jenjang masa tertentu saja, melainkan juga untuk sepanjang waktu dan sepanjang kehidupan manusia.

\section{Daftar Pustaka}

Al-Jaziry, Abd. Ar-Rahman, Kitab al-Fiqh 'Ala al-Mazahib al-Arba'ah (Beirut: Dar al-Fikr, t.t), II : 320. 
Al-Maraghi, Ahmad Mustafa. 1993. Tafsir al-Maraghi diterjemahkan oleh Bahrun Abu Bakar dkk., Semarang: Toha Putra.

Al-Son'any. 1995. Subulu Al-salam, terj: Abu bakar, Subulu Al-Salam. Surabaya: Al-Ikhlas.

Ash-Shiddieqy, Hasbi. 1984. Pengantar Fiqh Muamalah, Jakarta: Bulan Bintang. Asy-Syaukani, Nail al-Autar, Beirut: Dar al-Fkr, t.t, IV

Az-Zuhaili, Wahbah. al-Fiqh al-Islamy Wa Adillatuhu, (Beirut: Dar al-Fkr, t.t), V: 183.

Bank for International Settlements. 2009. Principles for Sound Stress Testing Practices and Supervision, Basel Committee on Banking Supervision, Switzerland,

Bukhory. Shahih Bukhory,Terj: Ahmad Sunarto dkk. 1992. Shahih Bukhory. Semarang: Asy-Syifa. Juz: 3 Al-Baihaqy, Sunan Al-Shagir. Beirut:Darul Kutub ilmiyah) Juz 1

Hamka. 1982. Tafsir al-Azhar juzu’ I, Jakarta: Pustaka Panjimas.

Ismal, Rifki. 2011. Simulation-Based Stress Testing, dalam Islamic Banking in Indonesia: new perspective on monetary and financial issues, Published by John Wiley \& Sons Singapore Pte. Ltd.

Hasan, M. Ali. 2004. Berbagai Macam Transaksi dala Islam, Cet. 2, Jakarta: PT. RajaGrafindo Persada.

Nafis, M. Cholil. 2011. Teori Hukum Ekonomi Syariah: Kajian Komprehensif tentang Teori Hukum Ekonomi Islam, Penerapannya dalam Fatwa Dewan Syariah Nasional dan Penyerapannya ke dalam Peraturan Perundang-undangan, Jakarta: UI-Press.

Nasution, Arman Hakim dan Baihaqi, Imam 2007. Simulasi Bisnis, Yogyakarta: Penerbit ANDI.

NBR Financial Stability and SPI Secretariat, 2007.Stress Testing Practices in Islamic Bank, "A paper prepared for the SPI Project Working Group

Siregar, Saparuddin,Mengembalikan Rahn Emas sebagai Produk Tabarru', dalam Bahan-bahan Terpilih dan Hasil Riset Terbaik, Forum Riset Perbankan Syariah III, IAIN Sumatera Utara Mendan, 29-30 September 2011. Ahmad al-Syarbashi, al-Mu'jam al-Iqtishadiy al-Islamiy, Dar al-jail: 1981

Suhendi, Hendi. 2008. Fiqh Muamalah, Jakarta: RajaGrafindo Persada. 
Syafe'i, Rachmat. 2001. Fiqih Muamalah, Bandung: Pustaka Setia.

Syafi'i, Rahmat. 1995. Konsep Gadai (rahn) dalam Fiqh Islam : Antara Nilai Sosial dan Nilai Komersial, dalam H. Chuzaimah T. Yanggo, HA. Hafiz Anshary AZ (edt) Problematika Hukum Islam Kontemporer, Buku Ketiga, Jakarta: PT. Pustaka Firdaus.

Syams al-Haq, Muhammad, 'Uwan al-Ma'bud Syarh Sunan Abu Dawud, Beirut: Dar al-Kutub al-'Ilmiyyah, cet. II, 1415, juz IV.

Visser, Hans. 2009. Islamic Finance Principles and Practice, (USA: Edward Elgar Publishing Limited.

Vogel, Frank E. dan Hayes, Samuel L. 2007. Hukum Keuangan Islam: Konsep, Teori dan Praktik, Terj. Bandung: Nusamedia.

Zuhdi. 1988. Masyfuk dalam Masail Fiqhiyah, Jakarta: CV. Haji Masagung. 